\title{
Editorial
}

\section{International Law in a Time of Pandemic}

To say that this issue of the Journal has been produced under unusual circumstances would be an understatement. When we began work on the issue in March 2020, the seriousness of the 'coronavirus disease 2019' ('COVID-19') outbreak was starting to become clear. Already in January, the Director-General of the World Health Organization (wHO) had declared the coviD-19 outbreak a 'public health emergency of international concern' (PHEIC), ${ }^{1}$ that is to say, as an 'extraordinary event' deemed under the International Health Regulations 'to constitute a public health risk to other States through the international spread of disease' and 'to potentially require a coordinated international response. ${ }^{2}$ In March, the Director-General further declared the outbreak a 'pandemic'. 3

The so-called Finagle's law of dynamic negatives (a somewhat lesser-known derivative of Murphy's law) postulates that 'anything that can go wrong, will at the worst possible moment'. This seems to have held true with respect to the COVID-19 outbreak from a global perspective. The pandemic hit during an era of increased scepticism in science, a decline of democracy and a rise of authoritarianism, a flare-up of big-power rivalry, and waning multilateralism. As a consequence, the response to COVID-19 became a political plaything both

1 Who Director-General, 'Statement on IHR Emergency Committee on Novel Coronavirus (2019-nCoV)' (30 January 2020) <www.who.int/dg/speeches/detail/who-director-general-s -statement-on-ihr-emergency-committee-on-novel-coronavirus-(2019-ncov) >.

2 International Health Regulations (2005), World Health Assembly Res WHA58.3 (23 May 2005) art 1.

3 wHo Director-General, 'Opening Remarks at the Media Briefing on Covid-19 (11 March 2020) $<$ www.who.int/dg/speeches/detail/who-director-general-s-opening-remarks-at-the -media-briefing-on-covid-19---11-march-2020>. 
domestically and internationally, and put serious strains on existing frameworks of global governance.

As editors, we decided to dedicate a significant portion of this issue to the international law implications of CoviD-19. But we probably underestimated the range of legal issues that the pandemic would generate. We originally had in mind a special section of the journal, with 3 or 4 short contributions, covering such things as the role of the WHO and human right implications of travel restrictions. We have ended up with ten diverse contributions, resulting in the largest issue of the journal published to date.

The contributions of Pouria Askary and Farzad Fallah, and Antonio Coco and Talita de Souza Dias, explore the broad range of obligations that States have in the context of a pandemic such as CoviD-19. Askary and Fallah focus on the right to international solidarity, with its three pillars of preventive solidarity, reactive solidarity and international cooperation. They argue that the principle of solidarity demands that States and other actors offer their assistance to the developing and less-developed States that are more affected by the pandemic. Coco and de Souza Diaz approach the matter through the lens of due diligence, which, as they explain, reflects a standard of good governance and derives from a number of different international law regimes. In the context of the pandemic, they identify four key types of due diligence obligations: capacity-building and preparedness, monitoring and reporting, response and mitigation, and international cooperation.

In their respective articles, Gian Luca Burci and Jan Klabbers focus on the role of шно and its Director-General, and the terms of the International Health Regulations. These contributions highlight the exceptional amount of public authority that the Director-General wields under the Regulations. Klabbers points out the significant flow-on effects of the Director-General's decisions, and the interests that need to be balanced whilst making these decisions, which explains why the Director-General initially acted somewhat cautiously. Burci argues that the Director-General's role was made more difficult by the absence of intermediate levels of alerts before a PHEIC is declared, by which point States had already taken measures that did not mesh with the wHO's recommendations.

Sarah Joseph and Natalie Klein address the rights of individuals from two different angles. Joseph focuses on the measures to manage the outbreak of covid-19 (including lockdowns, quarantine, testing and the rationing of some medical interventions) from an international human rights law perspective. She explains how States must balance rights to health and life against limitations that public health measures to contain the virus place on other human 
rights; she also notes that some States have succeeded better at this than others. Klein looks specifically at the plight of the passengers and crew members of cruise ships, which raises issues not only under international human rights law and international health law, but also under the law of the sea and the law of consular relations. Having examined the interaction of these legal regimes, she advocates for humanitarian considerations to be deemed the overriding concerns when operationalising the legal rules.

Barrie Sander and Nicholas Tsagourias, in their article, consider the role that has been played by a particularly influential category of private actors, namely online platforms. Sander and Tsagourias suggest that by interposing themselves in the COVID-19 context between States and the global community on the one hand and people on the other hand, online platforms become intermediary fiduciaries of the international public good of health. They argue that this requires legal regulation, which should, among other things, ensure that online platforms respect the human dignity of individuals as well as the legitimate interests of States.

Martins Paparinskis addresses the role of the law of international responsibility in disputes arising out of the way in which States and/or international organisations managed, or failed to manage, the pandemic. He raises the question as to whether the rules on international responsibility - for example, the rather narrow reading of the defence of necessity currently recognised under international law - will survive the covid-19-related State practice unscathed.

Two further papers help place the CoviD-19 crisis in a broader political and governance context. David Fidler examines the pandemic through the lens of geopolitics. He observes that while balance-of-power politics did not have a significant detrimental effect on global health initiatives during and immediately after the Cold War, the rivalry between the United States and China has intensified because of the COVID-19 outbreak. Balance-of-power considerations cast a shadow on public health responses to the pandemic and the global health enterprise more generally. Hin-Yan Liu, Kristian Lauta and Matthijs Maas consider the pandemic within the framework of global catastrophic risk and existential risk. They outline a range of possible readings of the adequacy of existing international law and global governance in the face of crises on the scale of CoviD-19. They also identify several challenges to a possible development of the regulatory framework to improve general existential risk preparedness. 
While coviD-19 dominated the airwaves for the better part of 2020, one ought not forget other crises, some of which have no doubt been aggravated by the pandemic. This issue also contains several contributions relating to other humanitarian emergencies and the relevant international legal framework more generally.

Martha Bradley focuses on the scope of application of the law of noninternational armed conflicts contained in Additional Protocol II to the Geneva Conventions. Against the background of conflicts in the Central African Republic, Mali, South Sudan and the Democratic Republic of the Congo, she interrogates the territorial control requirement found in Article 1(1) of the Protocol.

Kirsten Fisher examines the impact of the November 2019 authorisation given by the Pre-Trial Chamber of the International Criminal Court to the Prosecutor to investigate alleged crimes committed in Bangladesh and Myanmar. Fisher argues that such exercise of jurisdiction over offences originating in Myanmar, a non-party State to the Rome Statute, may have significant adverse effects for the Court and for vulnerable populations.

Alessandro Silvestri addresses the perennial problem of civilians losing their protection under the law of armed conflict where they take a direct part in hostilities. Silvestri focuses on the modalities of the loss of protection, seeking to develop a practical framework capable of being used in decision-making on the battlefield.

This issue wraps up with two reviews of books. In a review essay, Alexander Gilder discusses Alex Bellamy's World Peace (And How We Can Achieve It), whereas Hannes Jöbstl reviews Simon McKenzie's Disputed Territories and International Criminal Law: Israeli Settlements and the International Criminal Court.

As always, we are keen to hear from our readers and potential contributors. If you have an idea for a symposium, an article or a note, we would be happy to discuss it with you. Please email us at editors@jihls.net or individually at the addresses below. If you would like to review a book - or perhaps a film, play, series or graphic novel - do get in touch with our Reviews Editor, Dr Marco Longobardo (m.longobardo1@westminster.ac.uk). Thank you for reading, and we hope to hear from you. 


\section{Russell Buchan}

School of Law, University of Sheffield, Sheffield, United Kingdom

r.j.buchan@sheffield.ac.uk

\section{Emily Crawford}

The University of Sydney Law School, Sydney, Australia

emily.crawford@sydney.edu.au

\section{Rain Liivoja}

The University of Queensland Law School, Brisbane, Australia r.liivoja@uq.edu.au 